\title{
SHORT NOTICES
}

Mother Earth :

\section{Agriculture}

being Letters on Soil addressed to Professor R. G. Stapledon. By Prof. Gilbert Wooding Robinson. Pp. viii + 202. (London: Thomas Murby and Co., 1937.) 5s. $6 d$. net.

7 HIS is an interesting and useful little book for the general reader. Although couched in the form of letters, the material apparently consists of the author's lectures to first-year students of agricultural science, omitting the more complicated diagrams and tabular matter but retaining the occasional shafts of professorial humour which relieve the tedium of yearly repetition-at any rate for the lecturer. There are seventeen chapters, or letters; beginning with a discussion of soil material, they pass to a description of soil profiles and surveys and their bearing on problems of soil fertility and the correct agricultural utilization of the various soil types.

\section{Leguminous Forage Plants}

By Dr. D. H. Robinson. Pp. vii +119 . (London : Edward Arnold and Co., 1937.) 6s. net.

$\mathrm{T}$ HIS little book is not primarily designed for the expert, but rather to enable the inexperienced to identify the various legume crop plants that are grown in Great Britain, and to explain their agricultural uses. It accomplishes its purpose very well and is written in a clear and readable style. The account of each legume commences with a description illustrated with excellent drawings. This is followed by a short outline of the crop's agricultural uses. A typical chemical analysis is given for most of the legumes described.

The book contains a few inaccuracies which might be corrected in the next edition. Thus it is not true to say that the nodule bacteria from red clover cannot infect white clover. The variation in efficiency of different strains of nodule bacteria is an important and widespread characteristic and is by no means confined to the organisms that infect lucerme. The discavery of such strain differences amongst the lucerne nodule bacteria is incorrectly credited to the reviewer. The problem of clover sickness appears to be less simple than is suggested on p. 18, and cannot always be attributed either to eel-worm or Sclerotinia.

H. G. T.

Theory and Practice in the use of Fertilizers By Dr. Firman E. Bear. (Wiley Agricultural Series.) Second edition. Pp. ix +360 . (New York: John Wiley and Sons, Inc.; London : Chapman and Hall, Ltd., 1938.) 20s. net.

7 HIS well-known text-book, first printed in 1929, has now been brought up to date. During the last nine years the subject has made great strides in its chemical, engineering, and agronomic aspects, and within the limits of a single book, it is only possible to touch lightly on some of these. The form of the book remains unaltered, but sections are added dealing with the inclusion of dolomite in fertilizer mixtures for use on acid soils; the use of granular fertilizers; the addition of calcium sulphate to high analysis mixtures; and the rapid methods of soil analysis for 'available nutrients' now being extensively used in the United States and elsewhere. A new chapter has been added on the minor elements in soils and crops, and examples of the necessity for the provision of traces of boron, copper, iron, magnesium, manganese and zine are quoted, mainly from American sources.

\section{Anthropology and Archæology}

Other Men's Lives :

a Study of Primitive Peoples. By Sir George Dunbar. Pp. $x i v+355+1$ plate. (London : Ivor Nicholson and Watson, Ltd., 1938.) 10s. 6d. net.

$\mathrm{T}$ HIS book is difficult to handle fairly. It aims at giving an account of the mode of life of a primitive people as it develops from the stage of the simple hunter and food-gatherer to that of the small farmer at the point of transition from the use of stone to that of metal. The author describes the culture of the old and the new stone ages, and then passes on to give an account in considerable detail of the culture of the extinct Tasmanians and of the Indians of North America, who may be said to be, in a cultural sense, no less extinct. The book is brought to a close with a description of the Abors, the little-known, and for long inaccessible, people living between the Assam valley and the Tibetan borderland. These people are taken as exemplifying in modern times a type of culture which has been shown to have existed in the stone age.

Setting aside the question how far a modern so-called primitive people presents an exact analogy with a prehistoric stone age people, from which it is separated by a gap of thousands of years, Sir George Dunbar's book appeals primarily to the non-technical reader, since neither his account of the Tasmanians nor of the Indians of North America is other than a compilation. At the same time, although he is not in the professional sense an archæologist, his account of the peoples of the stone ages interprets the material with the eye of an ethnographer with first-hand acquaintance of how a people of simple culture really does live. In the concluding section of the book, however, the author records the results of his experience during some years of residence among a people in a stage of transition from stone to metal. If on this account alone, his book deserves the attention of the scientific anthropologist. 